\title{
Effect of Rice Husk Ash and Fly Ash on the workability of concrete mixture in the High-Rise Construction
}

\author{
Lam Van Tang ${ }^{1,}{ }^{*}$, Boris Bulgakov ${ }^{1}$,Sofia Bazhenova ${ }^{1}$, Olga Aleksandrova ${ }^{1}$, Anh Ngoc Pham $^{2}$ \\ and Tho Dinh $\mathrm{Vu}^{1}$ \\ ${ }^{1}$ Moscow State University of Civil Engineering, Yaroslavskoe shosse, 26, Moscow, 129337, Russia \\ ${ }^{2}$ Ruhr Universität Bochum, Bochum, Germany, IC 6-137 Universitätstr 150, 44801 Bochum
}

\begin{abstract}
The dense development of high-rise construction in urban areas requires a creation of new concretes with essential properties and innovative technologies for preparing concrete mixtures. Besides, it is necessary to develop new ways of presenting concrete mixture and keeping their mobility. This research uses the mathematical method of two-factors rotatable central compositional planning to imitate the effect of amount of rice husk (RHA) and fly ash of thermal power plants (FA) on the workability of high-mobility concrete mixtures. The results of this study displays regression equation of the second order dependence of the objective functions - slump cone and loss of concrete mixture mobility due to the input factors - the amounts RHA ( $\left.\mathrm{x}_{1}\right)$ and FA ( $\left.\mathrm{x}_{2}\right)$, as well as the surface expression image of these regression equations. An analysis of the regression equations also shows that the amount of RHA and FA had a significant influence on the concrete mixtures mobility. In fact, the particles of RHA and FA will play the role as peculiar "sliding bearings" between the grains of cement leading to the dispersion of cement in the concrete mixture. Therefore, it is possible to regulate the concrete mixture mobility when transporting fresh concrete to the formwork during the high-rise buildings construction in the hot and humid climate of Vietnam. Although the average value of slump test of freshly mixed concrete, measured 60 minutes later after the mixing completion, decreased from 18.2 to $10.52 \mathrm{~cm}$, this value still remained within the allowable range to maintain the mixing and and the delivery of concrete mixture by pumping.
\end{abstract}

\section{Introduction}

In fact, modern architecture and construction would hardly be possible without the use of concrete. It becomes more and more popular material to create durable, reliable and longlasting design, which can withstand atmospheric and mechanical influences since many years $[1,2]$. If there are no problems with the manufacture or acquisition of a concrete mixtures and its issues, the supply of concrete mix (especially in case of large volumes) will be one of the most important process in the whole technological chain of organizing the construction

* Corresponding author: lamvantang@gmail.com 
work. The 21 st century is considered to be the century of high-rise buildings construction. It is characterized by the global cities and dense urban where are shortage of free spaces, growing demand of residential and commercial areas. These requirement will be fundamentally leading to the emergence of new town-planning concepts, including high-rise construction concept [3]. In reality, it can be said that fresh concrete mix is a rather specific material, which gradually loses its workability as hydration of the binder. Thus, this mix must be protected from sunlight, precipitation, freezing and quickly delivered to the construction site in required operating condition without any loss of quality and deterioration properties [4]. Depending on the type of buildings, the parameters of the concrete mixture and its volume are supplied by the following method [5-7]:

1. Directly applying concrete mixture to the structure from the concrete conveyor or with the help of bunker and overpasses. The main disadvantage of this approach is the limitation of application range as well as unusable for high-rise buildings.

2. Applying concrete mixture by bunker with the help of crane. These disadvantages of this method are the need to add an overload to the concrete mixture and waste time of crane installation.

3. Applying concrete mixture by belt conveyor that is stationary or mobile system based on a car or tractor. The working arrows of $10 \div 20 \mathrm{~m}$ length are used, where the conveyer belt is moving from the concrete mixture. This method is effective only for a large amount of work. It is used in the concrete structures of the zero cycle: foundations, basement walls, floors, ceilings, etc., and above-ground parts of buildings (not higher than two stories - up to $4 \div 6 \mathrm{~m}$ ).

4. Applying concrete mixture by pumping. This method is used for large volumes of concrete in buildings and space constraints (Fig. 1).

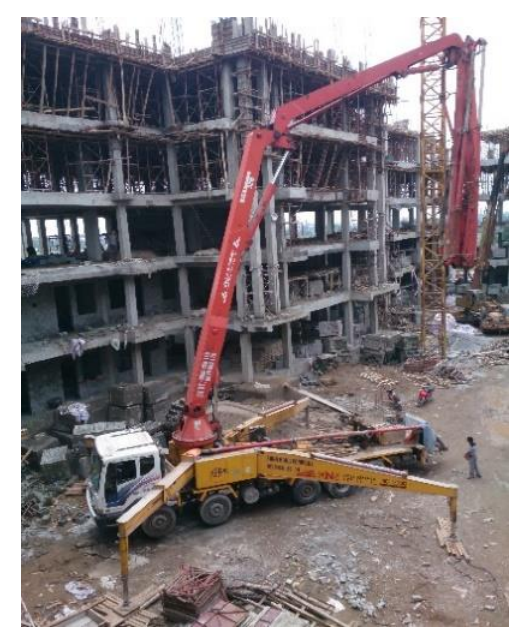

Fig. 1. Pumping concrete mixture through pipelines in the high-rise constructions in Hanoi (Vietnam)

Concrete mixture with a slump cone standard of 8 to $18 \mathrm{~cm}$ [8-10], which corresponds to the parameters of concrete mixtures are used in the hot and humid climate of Vietnam [11], is applied directly to the concrete structure through steel pipes (diameter of $100 \div 200 \mathrm{~mm}$ ). The distance and height application are up to $150 \mathrm{~m}$ and $40 \mathrm{~m}$ respectively.

Practically, in high-rise construction, depending on the building object's parameters (width, height, degree of restraint, etc.), one of the following technological schemes is being used:

- All the equipment is installed at the base of the truck mixer. This system can operate in transport mode: the concrete mixture at the plant is delivered to the facility and submitted to 
the installation place. It is also possible to work in a stationary mode to prepare the concrete mixture directly and apply to the installation area of the constructions.

- All equipment is mounted on the chassis of the car. The concrete mixture is delivered by other transport (dump truck or auto mixers) and loaded into the unit receiver hopper

- All equipment is mounted on the tower crane of structures.

- Using separate stationary equipment for high-rise buildings and structures construction: the receiving bunker and concrete pump are located on the ground; the boom-crane with an autonomous drive is installed on the working horizon and shifted upwards during the construction as required. The concrete mixture is applied to the vertical main pipe, which is also increased by the building erection.

The advantages of the pneumatic method in feeding a concrete mixture are high productivity, unused cranes and the possible application at any point.

This method's disadvantages are the limitations on the parameters of the mixture and the size of the aggregate (less than $40 \mathrm{~mm}$ ), as well as the high costs to flush the pipelines.

The result of this study [12] shows that for concrete mixtures in high-rise construction, the filler selection and superplasticizers usage for ease of transportation in pumping are greatly important.

According to the studies [13, 14], a very important problem for concrete mixture, which is transported by pumping, is the necessary to ensure the stability of working ability in time. In addition, in order to provide the pipeline lubrication during the delivery of concrete pump, the concrete mixture composition must be sufficiently large number of component mortar (consisting of cement, sand, water, plasticizer and mineral filler). According to the result of this study [11], the percentage of mortar in the concrete mixture should be in the range of 40 and $44 \%$.

Based on the above analysis, it can be concluded that using both superplasticizers and fine-graded mineral fillers (for example, fly ash of thermal power plants (FA TPP), rice husk ash (RHA), microsilica, metakaolin and so on) is an important factor in improving the pumpability and influencing the persistence of high-mobility concrete mixes.

This paper mainly focuses on the effects of rice husk ash and fly ash from TPP "Vung Ang" on the working ability of the concrete mixture and its loss for different time periods by the form of second-order regression equations.

\section{Materials and Methods}

\subsection{Materials}

- Portland Cement (PC) type SEM II 42.5 N manufactured at "Nghi Son" factory (Viet Nam). The characteristics of this Portland cement and the experimental results obtained for testing its properties are shown in Table 1.

- Standard quartz sand (QS) of Science and Technology Institute building (Vietnam): $\mathrm{M}_{\mathrm{K}}$ $=2.85$, specific weight of $2.65 \mathrm{~g} / \mathrm{cm}^{3}$ and the volume of compacted state is $1540 \mathrm{~kg} / \mathrm{m}^{3}$.

- Crushed limestone (CL) produced from the quarry "Kien Khe" (Vietnam) with the size of $5-10 \mathrm{~mm}$, specific weight of $2.61 \mathrm{~g} / \mathrm{cm}^{3}$ and volume of the compacted state is $1620 \mathrm{~kg} / \mathrm{m}^{3}$.

Table 1. Physical and mechanical properties of Portland цемент SEM II $42.5 \mathrm{~N}$ "Nghi Son"

\begin{tabular}{|c|c|c|c|c|c|c|c|}
\hline \multirow{2}{*}{$\begin{array}{c}\text { Specific } \\
\text { weight } \\
\left(\mathrm{g} / \mathrm{cm}^{3}\right)\end{array}$} & \multicolumn{3}{|c|}{ Fineness } & \multicolumn{2}{|c|}{$\begin{array}{c}\text { Time of setting } \\
\text { (min) }\end{array}$} & $\begin{array}{c}\text { Compressive } \\
\text { strength (MPa) }\end{array}$ & $\begin{array}{c}\text { Water } \\
\text { requirement } \\
(\%)\end{array}$ \\
\cline { 2 - 8 } & $\begin{array}{c}\text { Retained content on } \\
\text { sieve №009 }(\%)\end{array}$ & $\begin{array}{c}\text { Specific surface } \\
\left(\mathrm{cm}^{2} / \mathrm{g}\right)\end{array}$ & Initial & Final & 2 days & 28 days & \\
\hline 3.12 & 3.8 & 3635 & 140 & 230 & 34.61 & 48.3 & 28.58 \\
\hline
\end{tabular}


- Superplasticizer ACE 388 (A388) “Sure Tec” BASF (Germany). It is a new generation chemical additives based on polycarboxylate ethers with specific weight of $1.1 \mathrm{~g} / \mathrm{cm}^{3}$ at $20 \pm$ $5^{\circ} \mathrm{C}$. The amount of $\mathrm{A} 388$ is $1 \%$ by the mass of Portland cement and the decrease of water content of the concrete mixture is about $30 \%$.

- Fly Ash (FA) from TPP "Vung Ang" (Vietnam) Class C and rice husk ash (RHA). According to the results [15-17], chemical composition and physical properties of RHA and FA ТЭС "Vung Ang" are presented in Table 2 and 3.

Table 2. Chemical compositions of RHA and FA TPP "Vung Ang"

\begin{tabular}{|c|c|c|c|c|c|c|c|c|c|c|c|}
\hline \multirow{2}{*}{ Mineral additives } & \multicolumn{10}{|c|}{ Average chemical composition (\%) } \\
\cline { 2 - 12 } & $\mathrm{SiO}_{2}$ & $\mathrm{Al}_{2} \mathrm{O}_{3}$ & $\mathrm{Fe}_{2} \mathrm{O}_{3}$ & $\mathrm{SO}_{3}$ & $\mathrm{~K}_{2} \mathrm{O}$ & $\mathrm{Na}_{2} \mathrm{O}$ & $\mathrm{MgO}$ & $\mathrm{CaO}$ & $\mathrm{TiO}_{2}$ & $\mathrm{P}_{2} \mathrm{O}_{5}$ & LOI $^{*}$ \\
\hline RHA & 88.2 & 1.25 & 1.75 & 0.5 & 1.14 & 2.67 & 0.8 & 0.52 & 0.15 & 0.25 & 2.77 \\
\hline FA & 54.62 & 25.17 & 7.11 & 0.25 & 1.28 & 0.2 & 1.57 & 1.45 & 1.83 & 1.63 & 2.04 \\
\hline
\end{tabular}

Note: LOI - loss on ignition.

Table 3. Physical properties of RHA and FA TPP "Vung Ang"

\begin{tabular}{|l|c|c|}
\hline \multicolumn{1}{|c|}{ Features } & RHA & FA TPP "Vung Ang" \\
\hline Specific weight $\left(\mathrm{g} / \mathrm{cm}^{3}\right)$ & 2.15 & 2.22 \\
\hline The volume of natural porous state $\left(\mathrm{kg} / \mathrm{m}^{3}\right)$ & 572 & 765 \\
\hline Specific surface area $\left(\mathrm{m}^{2} / \mathrm{g}\right)$ & 11.350 & 14.455 \\
\hline Humidity $(\%)$ & 2 & 11 \\
\hline Retained content on sieve with a hole size of $45 \mu \mathrm{m}(\%)$ & 23.2 & 31 \\
\hline Water requirement $(\%)$ & 100.7 & 104.1 \\
\hline
\end{tabular}

\subsection{Methods}

- Calculation preliminary compositions method of concrete mixture is applied in accordance with ACI 211.4R-93 (American).

- The work ability of concrete mixture is determined by the slump of cone standard with dimensions of $100 \times 200 \times 300 \mathrm{~mm}$.

- The mathematical modeling, depicting the dependence of RHA and FA TPP "Vung Ang" on the work ability of the concrete mixture, uses the rotatable central compositional planning method for two-factors.

\section{Results and discussion}

In this paper, correlation analysis made it possible to establish the mathematical dependence of standard slump cone of high-mobility concrete mixtures, which was measured at different time intervals after completion of mixing of raw materials, on the amount of RHA and FA of TPP "Vung Ang" by using Central composite rotatable design (CCRD) method for two factors $[20$ - 22].

CCRD method allows to obtain a more accurately mathematical description by increasing the number of experiments at the center and some special values of "star shoulder" $\alpha=$ $\sqrt{2}=1.414$ [23]. Matrix of the CCRD for two factors are presented in Table 4 . 
Table 4. Matrix of the CCRD for two factors

\begin{tabular}{|c|c|c|c|c|c|c|c|c|}
\hline \multirow{2}{*}{$\begin{array}{l}\text { Sestems of } \\
\text { experiments }\end{array}$} & \multirow{2}{*}{ Trial No } & \multicolumn{6}{|c|}{ Description of code } & \multirow{2}{*}{$\mathrm{Y}_{\mathrm{j}}$} \\
\hline & & $\mathrm{x}_{0}$ & $\mathrm{x}_{1}$ & $\mathrm{x}_{2}$ & $\mathrm{x}_{1} \mathrm{x}_{2}$ & $\mathrm{x}^{2}{ }_{1}$ & $\mathrm{x}^{2}{ }_{2}$ & \\
\hline \multirow{4}{*}{$\begin{array}{l}\text { Number of } \\
\text { experiments } \\
\text { in the core of } \\
\text { the plan }\end{array}$} & 1 & +1 & +1 & +1 & +1 & +1 & +1 & $\mathrm{Y}_{1}$ \\
\hline & 2 & +1 & -1 & +1 & -1 & +1 & +1 & $\mathrm{Y}_{2}$ \\
\hline & 3 & +1 & +1 & -1 & -1 & +1 & +1 & $\mathrm{Y}_{3}$ \\
\hline & 4 & +1 & -1 & -1 & +1 & +1 & +1 & $\mathrm{Y}_{4}$ \\
\hline \multirow{4}{*}{$\begin{array}{c}\text { Number of } \\
\text { experiments } \\
\text { in "Star } \\
\text { points" }\end{array}$} & 5 & +1 & +1.414 & 0 & 0 & 2 & 0 & $\mathrm{Y}_{5}$ \\
\hline & 6 & +1 & -1.414 & 0 & 0 & 2 & 0 & $\mathrm{Y}_{6}$ \\
\hline & 7 & +1 & 0 & +1.414 & 0 & 0 & 2 & $\mathrm{Y}_{7}$ \\
\hline & 8 & +1 & 0 & -1.414 & 0 & 0 & 2 & $\mathrm{Y}_{8}$ \\
\hline \multirow{5}{*}{$\begin{array}{c}\text { Number of } \\
\text { experiments } \\
\text { in the center } \\
\text { of the plan }\end{array}$} & 9 & +1 & 0 & 0 & 0 & 0 & 0 & $\mathrm{Y}_{9}$ \\
\hline & 10 & +1 & 0 & 0 & 0 & 0 & 0 & $\mathrm{Y}_{10}$ \\
\hline & 11 & +1 & 0 & 0 & 0 & 0 & 0 & $\mathrm{Y}_{11}$ \\
\hline & 12 & +1 & 0 & 0 & 0 & 0 & 0 & $\mathrm{Y}_{12}$ \\
\hline & 13 & +1 & 0 & 0 & 0 & 0 & 0 & $Y_{13}$ \\
\hline
\end{tabular}

The determination of the preliminary composition of concrete mixture with standard slump cone from 15 to $20 \mathrm{~cm}$ allows to achieve concrete with the compressive strength of 70 $\mathrm{MPa}$ at the age of 28 days according to American standard ACI 211.4R-93. These results are shown in Table. 5.

Table 5. Preliminary compositions, properties of concrete mixture and concrete

\begin{tabular}{|c|c|c|c|c|c|c|c|c|c|c|}
\hline \multicolumn{7}{|c|}{ Compositions of concrete mixture $\left(\mathrm{kg} / \mathrm{m}^{3}\right)$} & \multicolumn{3}{|c|}{ Properties of concrete mixture } & \multirow{2}{*}{$\begin{array}{c}\text { Compressive } \\
\text { strength at } 28 \\
\text { days (MPa) }\end{array}$} \\
\hline PC & RHA & FA & QS & CL & W & A388 & $\begin{array}{c}\text { Average } \\
\text { density } \\
\left(\mathrm{kg} / \mathrm{m}^{3}\right)\end{array}$ & $\frac{\mathrm{W}}{\mathrm{BID}}$ & $\begin{array}{l}\text { Slump cone } \\
(\mathrm{mm})\end{array}$ & \\
\hline 392 & 59 & 118 & 537 & 1053 & 159 & 3.92 & 2319.7 & 0.28 & 18.0 & 71.5 \\
\hline
\end{tabular}

The water-binding ratio is constant and equal to $\frac{\mathrm{W}}{\mathrm{BID}}=0.28$. The amount of superplasticizer A388 is $1 \%$ by the mass of PC.

The amounts of RHA and FA in the concrete mixture are chosen, respectively, in the range from $8 \%$ to $22 \%$ and from $20 \%$ to $40 \%$ by the mass of PC. While the contents of QS is $537 \mathrm{~kg}$ and $\mathrm{CL}$ is $1053 \mathrm{~kg}$.

Description of objective functions of the empirical model:

Yi $(\mathrm{i}=0,30$ and 60$)$ - the slump cone of the high-mobility concrete mixtures $(\mathrm{cm})$ at time of 0,30 and 60 minutes are considered as an objective functions of the experimental model.

Input factors and their limitations are sorted as below:

- The amount of RHA is factor $\mathrm{x}_{1}$ in the range from 0.08 to 0.22 by mass PC.

- The amount of FA is factor $\mathrm{x}_{2}$ in the range from 0.2 to 0.4 by mass PC.

Table 6 presents the input factors and their variation intervals.

Table 6. Levels and intervals of varying factors of the CCRD

\begin{tabular}{|c|c|c|c|c|c|c|c|}
\hline \multirow{2}{*}{ Parameter factors } & \multirow{2}{*}{$\begin{array}{c}\text { Description } \\
\text { factors }\end{array}$} & \multicolumn{5}{|c|}{ Levels varying factors } & \multirow{2}{*}{$\begin{array}{c}\text { Intervals varying } \\
\text { factors }\end{array}$} \\
\cline { 3 - 7 } & & -1.414 & -1 & 0 & +1 & +1.414 & 0.07 and 0.0083 \\
\hline Amount of RHA & $\mathrm{x}_{1}$ & 0.0717 & 0.08 & 0.15 & 0.22 & 0.2283 & 0.07 and \\
\hline Amount of FA & $\mathrm{x}_{2}$ & 0.2067 & 0.215 & 0.3 & 0.385 & 0.3933 & 0.085 and 0.0083 \\
\hline
\end{tabular}


The number experiments of CCRD for the two factors is indicated by formula (1):

$$
N=2^{\mathrm{k}}+2 \times \mathrm{k}+\mathrm{m}
$$

where: $\mathrm{k}$ - the number of factors, $\mathrm{k}=2$;

$\mathrm{m}-$ the number of repeating experiments at the center of model, $\mathrm{m}=5$ according to [23].

Substitution into formula (1) obtained: $N=2^{2}+2 \times 2+5=13$.

Compositions of high-mobility concrete mixtures, which were calculated by the method of central composite rotatable design for two factors, are displayed in Table 7. The values of slump cone of concrete mixture are measured in centimeter immediately after the completion of the mixing of the raw materials. These values after 30 and 60 minutes are presented in Tables $8-10$.

Table 7. Compositions of concrete mixtures in the CCRD for two factors

\begin{tabular}{|c|c|c|c|c|c|c|c|c|c|c|c|}
\hline \multirow{2}{*}{$\begin{array}{c}\text { Trial } \\
\text { No. }\end{array}$} & \multicolumn{2}{|c|}{ Description of code } & \multicolumn{3}{|c|}{ Parameter factors } & \multicolumn{5}{|c|}{ Compositions of concrete mixtures $\left(\mathrm{kg} / \mathrm{m}^{3}\right)$} \\
\hline & $\mathrm{x}_{1}$ & $\mathrm{x}_{2}$ & RHA & FA & PC & RHA & FA & QS & CL & W & A388 \\
\hline 1 & +1 & +1 & 0.22 & 0.385 & 348 & 77 & 134 & 537 & 1053 & 157 & 3.5 \\
\hline 2 & -1 & +1 & 0.08 & 0.385 & 386 & 31 & 149 & 537 & 1053 & 158 & 3.9 \\
\hline 3 & +1 & -1 & 0.22 & 0.215 & 395 & 87 & 85 & 537 & 1053 & 159 & 4 \\
\hline 4 & -1 & -1 & 0.08 & 0.215 & 445 & 36 & 96 & 537 & 1053 & 162 & 4.5 \\
\hline 5 & +1.414 & 0 & 0.2283 & 0.3 & 368 & 84 & 110 & 537 & 1053 & 157 & 3.7 \\
\hline 6 & -1.414 & 0 & 0.0717 & 0.3 & 417 & 30 & 125 & 537 & 1053 & 160 & 4.2 \\
\hline 7 & 0 & +1.414 & 0.15 & 0.3933 & 364 & 55 & 143 & 537 & 1053 & 157 & 3.6 \\
\hline 8 & 0 & -1.414 & 0.15 & 0.2067 & 421 & 63 & 87 & 537 & 1053 & 160 & 4.2 \\
\hline 9 & 0 & 0 & 0.15 & 0.3 & 391 & 59 & 117 & 537 & 1053 & 159 & 3.9 \\
\hline 10 & 0 & 0 & 0.15 & 0.3 & 391 & 59 & 117 & 537 & 1053 & 159 & 3.9 \\
\hline 11 & 0 & 0 & 0.15 & 0.3 & 391 & 59 & 117 & 537 & 1053 & 159 & 3.9 \\
\hline 12 & 0 & 0 & 0.15 & 0.3 & 391 & 59 & 117 & 537 & 1053 & 159 & 3.9 \\
\hline 13 & 0 & 0 & 0.15 & 0.3 & 391 & 59 & 117 & 537 & 1053 & 159 & 3.9 \\
\hline
\end{tabular}

Table 8. Values of slump cone of concrete mixtures after immediately mixing completion

\begin{tabular}{|c|c|c|c|c|c|c|c|c|c|c|c|}
\hline \multirow{2}{*}{$\begin{array}{c}\text { Trial } \\
\text { No. }\end{array}$} & \multicolumn{6}{|c|}{ Description of code } & \multicolumn{2}{|c|}{$Y_{0}(\mathbf{c m})$} & \multirow{2}{*}{\multicolumn{2}{|c|}{$\left(Y_{1 j}-\hat{Y}_{1 j}\right)^{2}$}} & \multirow{2}{*}{$\left(Y_{01 j}-\widehat{Y}_{01 j}\right)^{2}$} \\
\hline & $\mathbf{x}_{0}$ & $\mathbf{x}_{1}$ & $\mathbf{x}_{2}$ & $\mathbf{x}_{1} \mathbf{x}_{2}$ & $\mathbf{x}_{1}^{2}$ & $\mathbf{x}_{2}^{2}$ & $\mathbf{Y}_{1 \mathrm{j}}$ & $\widehat{\mathrm{Y}}_{1 \mathrm{j}}$ & & & \\
\hline 1 & +1 & +1 & +1 & 1 & 1 & 1 & 15.8 & 15.73 & & 0.005 & - \\
\hline 2 & +1 & -1 & +1 & -1 & 1 & 1 & 17.0 & 17.15 & & 0.023 & - \\
\hline 3 & +1 & +1 & -1 & -1 & 1 & 1 & 18.2 & 18.07 & & 0.017 & - \\
\hline 4 & +1 & -1 & -1 & 1 & 1 & 1 & 20.0 & 19.49 & & 0.26 & - \\
\hline 5 & +1 & +1.414 & 0 & 0 & 2 & 0 & 16.7 & 16.73 & & 0.001 & - \\
\hline 6 & +1 & \begin{tabular}{|l|}
-1.414 \\
\end{tabular} & 0 & 0 & 2 & 0 & 18.6 & 18.74 & & 0.019 & - \\
\hline 7 & +1 & 0 & +1.414 & 0 & 0 & 2 & 16.0 & 15.83 & & 0.029 & - \\
\hline 8 & +1 & 0 & -1.414 & 0 & 0 & 2 & 18.8 & 19.14 & & 0.115 & - \\
\hline 9 & +1 & 0 & 0 & 0 & 0 & 0 & 18.3 & 18.2 & & 0.01 & 0.01 \\
\hline 10 & +1 & 0 & 0 & 0 & 0 & 0 & 18.2 & 18.2 & & 0 & 0 \\
\hline 11 & +1 & 0 & 0 & 0 & 0 & 0 & 18.3 & 18.2 & & 0.01 & 0.01 \\
\hline 12 & +1 & 0 & 0 & 0 & 0 & 0 & 18.0 & 18.2 & & 0.04 & 0.04 \\
\hline 13 & +1 & 0 & 0 & 0 & 0 & 0 & 18.2 & 18.2 & & 0 & 0 \\
\hline \multicolumn{4}{|c|}{$\sum\left(Y_{1 j}-\hat{Y}_{1 j}\right)^{2}=0.529$} & \multicolumn{3}{|c|}{$\mathrm{S}_{\mathrm{d}}^{2}=0.066$} & \multicolumn{3}{|c|}{$\sum\left(\mathrm{Y}_{01 \mathrm{j}}-\widehat{\mathrm{Y}}_{01 \mathrm{j}}\right)^{2}=0.06$} & $\mathrm{~S}_{\mathrm{II}}^{2}=0.015$ & $\overline{\mathrm{Y}}_{0}=18.20$ \\
\hline
\end{tabular}


Table 9. Values of slump cone of concrete mixtures after 30 minutes of mixing completion

\begin{tabular}{|c|c|c|c|c|c|c|c|c|c|c|}
\hline $\begin{array}{c}\text { Trial } \\
\text { No. }\end{array}$ & $\mathbf{x}_{\mathbf{0}}$ & $\mathbf{x}_{\mathbf{1}}$ & $\mathbf{x}_{\mathbf{2}}$ & $\mathbf{x}_{\mathbf{1}} \mathbf{x}_{\mathbf{2}}$ & $\mathbf{x}_{\mathbf{1}}{ }^{\mathbf{2}}$ & $\mathbf{x}_{\mathbf{2}}{ }^{\mathbf{2}}$ & $\mathbf{Y}_{\mathbf{1 j}}$ & $\hat{\mathrm{Y}}_{1 \mathrm{j}}$ & \multirow{2}{*}{$\left(\mathrm{Y}_{1 \mathrm{j}}-\widehat{\mathrm{Y}}_{1 \mathrm{j}}\right)^{2}$} & \multirow{2}{*}{$\left(\mathrm{Y}_{01 \mathrm{j}}-\widehat{\mathrm{Y}}_{01 \mathrm{j}}\right)^{2}$} \\
\hline 1 & +1 & +1 & +1 & 1 & 1 & 1 & 13.0 & 12.70 & 0.092 & - \\
\hline 2 & +1 & -1 & +1 & -1 & 1 & 1 & 13.5 & 14.13 & 0.397 & - \\
\hline 3 & +1 & +1 & -1 & -1 & 1 & 1 & 15.5 & 15.45 & 0.003 & - \\
\hline 4 & +1 & -1 & -1 & 1 & 1 & 1 & 17.2 & 16.88 & 0.101 & - \\
\hline 5 & +1 & +1.414 & 0 & 0 & 2 & 0 & 13.5 & 13.70 & 0.040 & - \\
\hline 6 & +1 & -1.414 & 0 & 0 & 2 & 0 & 16.0 & 15.73 & 0.074 & - \\
\hline 7 & +1 & 0 & +1.414 & 0 & 0 & 2 & 13.2 & 12.92 & 0.079 & - \\
\hline 8 & +1 & 0 & -1.414 & 0 & 0 & 2 & 16.6 & 16.81 & 0.044 & - \\
\hline 9 & +1 & 0 & 0 & 0 & 0 & 0 & 14.2 & 14.34 & 0.020 & 0.020 \\
\hline 10 & +1 & 0 & 0 & 0 & 0 & 0 & 14.5 & 14.34 & 0.026 & 0.026 \\
\hline 11 & +1 & 0 & 0 & 0 & 0 & 0 & 14.4 & 14.34 & 0.004 & 0.004 \\
\hline 12 & +1 & 0 & 0 & 0 & 0 & 0 & 14.0 & 14.34 & 0.116 & 0.116 \\
\hline 13 & +1 & 0 & 0 & 0 & 0 & 0 & 14.6 & 14.34 & 0.068 & 0.068 \\
\hline$\sum$
\end{tabular}

Table 10. Values of slump cone of concrete mixtures after 60 minutes of mixing completion

\begin{tabular}{|c|c|c|c|c|c|c|c|c|c|c|}
\hline \multirow{2}{*}{$\begin{array}{c}\text { Trial } \\
\text { No. }\end{array}$} & $\mathrm{x}_{0}$ & $\mathrm{x}_{1}$ & $\mathrm{x} 2$ & $\mathrm{x} 1 \mathrm{x} 2^{2}$ & $\mathrm{x}^{2}$ & $\mathrm{x}_{2}{ }^{2}$ & $\mathrm{Y}_{1 \mathrm{j}}$ & $\hat{\mathrm{Y}}_{1 \mathrm{j}}$ & \multirow{2}{*}{$\left(\mathrm{Y}_{1 \mathrm{j}}-\mathrm{Y}_{1 \mathrm{j}}\right)^{2}$} & \multirow{2}{*}{$\left(\mathrm{Y}_{01 \mathrm{j}}-\mathrm{Y}_{01 \mathrm{j}}\right)^{2}$} \\
\hline 1 & +1 & +1 & +1 & 1 & 1 & 1 & 8.5 & 8.21 & 0.085 & - \\
\hline 2 & +1 & -1 & +1 & -1 & 1 & 1 & 9.6 & 10.24 & 0.414 & - \\
\hline 3 & +1 & +1 & -1 & -1 & 1 & 1 & 11.2 & 11.40 & 0.039 & - \\
\hline 4 & +1 & -1 & -1 & 1 & 1 & 1 & 14.0 & 13.43 & 0.322 & - \\
\hline 5 & +1 & +1.414 & 0 & 0 & 2 & 0 & 9.2 & 9.23 & 0.001 & - \\
\hline 6 & +1 & -1.414 & 0 & 0 & 2 & 0 & 12.2 & 12.11 & 0.008 & - \\
\hline 7 & +1 & 0 & +1.414 & 0 & 0 & 2 & 9.0 & 8.72 & 0.081 & - \\
\hline 8 & +1 & 0 & -1.414 & 0 & 0 & 2 & 13.0 & 13.22 & 0.051 & - \\
\hline 9 & +1 & 0 & 0 & 0 & 0 & 0 & 10.5 & 10.52 & 0.000 & 0.000 \\
\hline 10 & +1 & 0 & 0 & 0 & 0 & 0 & 10.8 & 10.52 & 0.078 & 0.078 \\
\hline 11 & +1 & 0 & 0 & 0 & 0 & 0 & 10.6 & 10.52 & 0.006 & 0.006 \\
\hline 12 & +1 & 0 & 0 & 0 & 0 & 0 & 10.4 & 10.52 & 0.014 & 0.014 \\
\hline 13 & +1 & 0 & 0 & 0 & 0 & 0 & 10.3 & 10.52 & 0.048 & 0.048 \\
\hline
\end{tabular}

The computer program Matlab provides regression equation (2), (3) and (4):

$$
\begin{gathered}
\mathrm{y}_{0}=18.2-0.7109 \mathrm{x}_{1}-1.17 \mathrm{x}_{2}+0.15 \mathrm{x}_{1} \mathrm{x}_{2}-0.2188 \mathrm{x}_{1}^{2}-0.3438 \mathrm{x}_{2}^{2}(\mathrm{~cm}) . \\
\mathrm{y}_{30}=14.34-0.717 \mathrm{x}_{1}-1.376 \mathrm{x}_{2}+0.3 \mathrm{x}_{1} \mathrm{x}_{2}+0.1988 \mathrm{x}_{1}^{2}+0.2738 \mathrm{x}_{2}^{2}(\mathrm{~cm}) . \\
\mathrm{y}_{60}=10.52-1.018 \mathrm{x}_{1}-1.595 \mathrm{x}_{2}+0.425 \mathrm{x}_{1} \mathrm{x}_{2}+0.0838 \mathrm{x}_{1}^{2}+0.2338 \mathrm{x}_{2}^{2}(\mathrm{~cm}) .
\end{gathered}
$$

By using Matlab program, the images of response surface and corresponding contour plot of the regression equations (2), (3) and (4) are shown in Fig. $2-4$. 

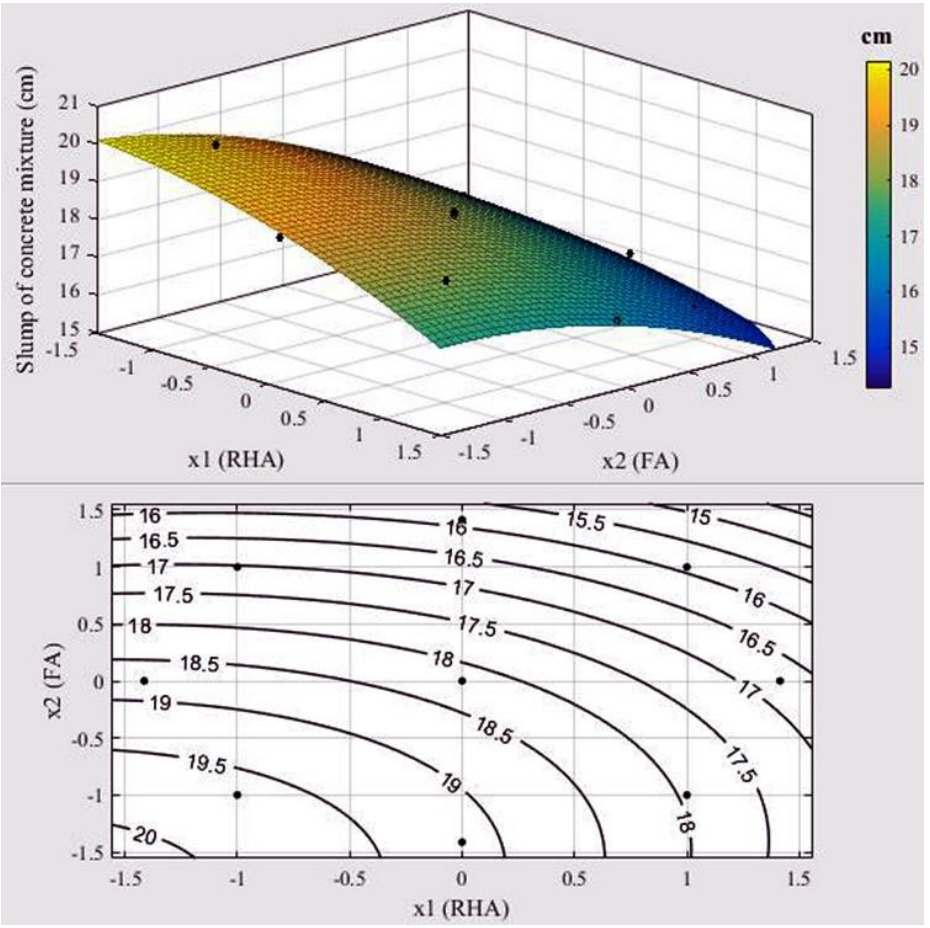

Fig. 2. The image of response surface and corresponding contour plot of the regression equations (2)
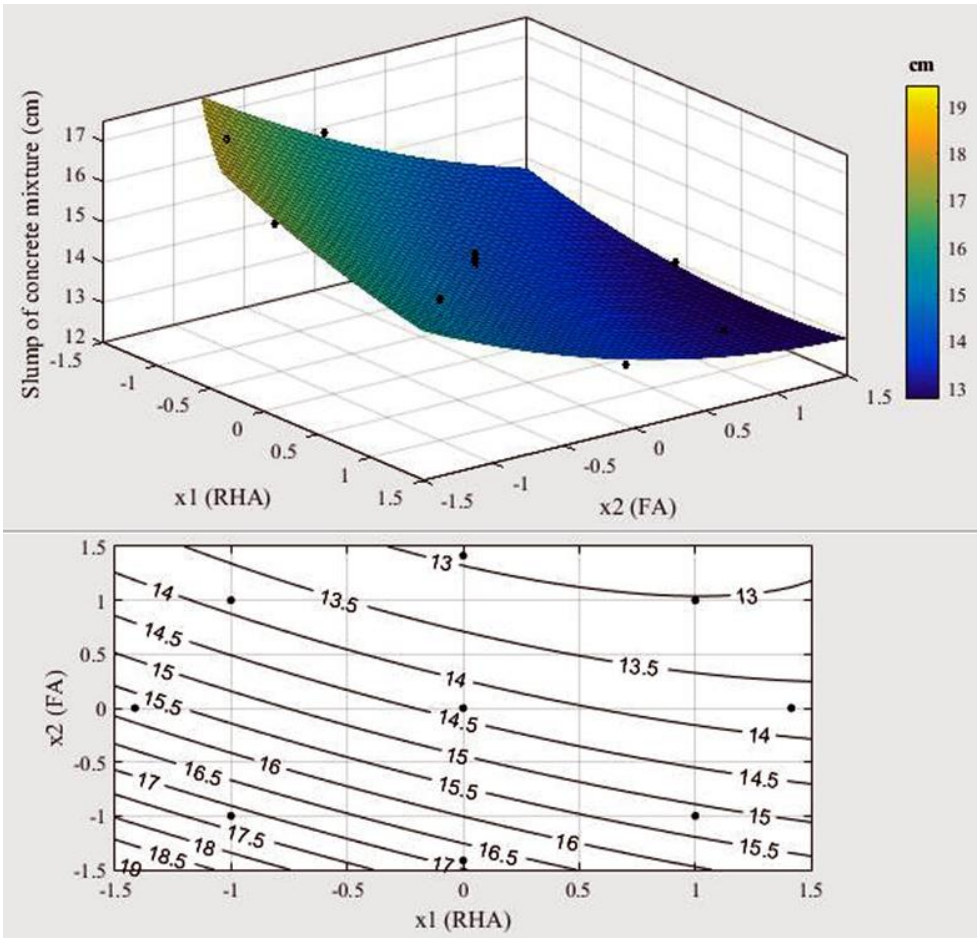

Fig. 3. The image of response surface and corresponding contour plot of the regression equations (3) 


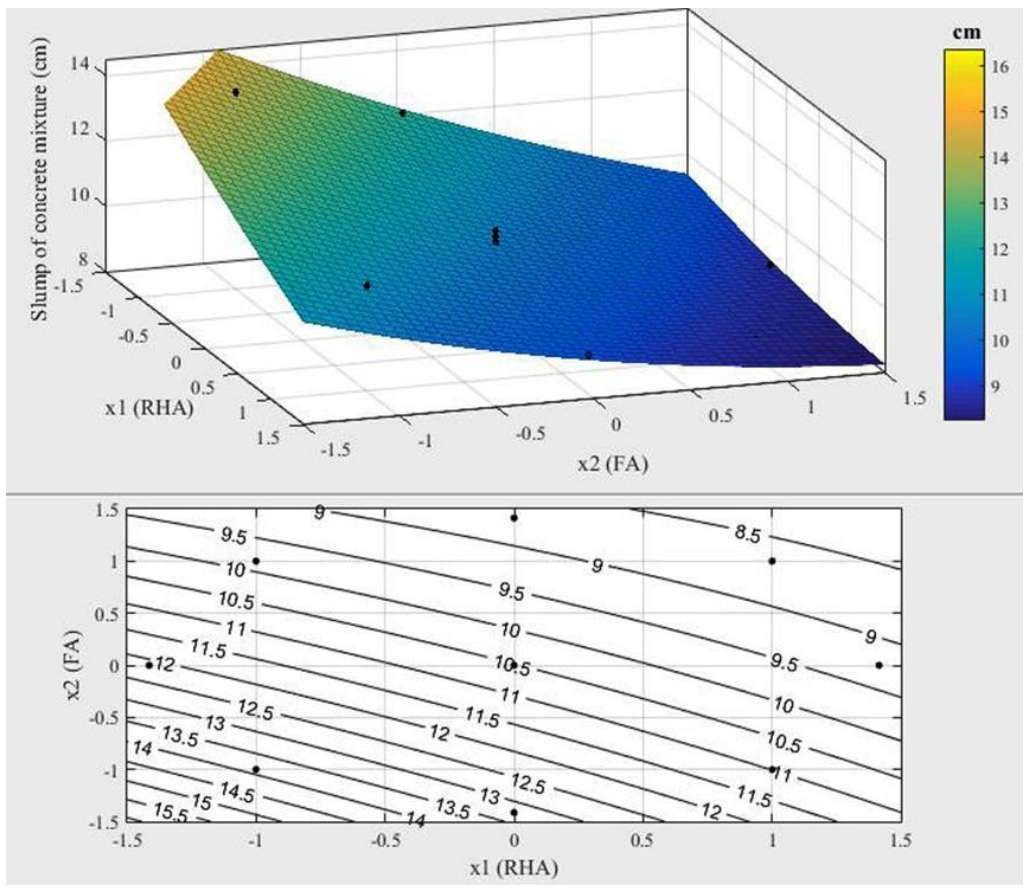

Fig. 4. The image of response surface and corresponding contour plot of the regression equations (4)

\section{Checking the significant coefficients of regression equations}

The significant coefficients of the regression equations were determined statistically by the Student's criterion $\left(t_{\alpha}\left(f_{2}\right)\right)$. The coefficient $b_{j}$ is considered significant if:

$$
t_{b j} \geq t_{\alpha}\left(f_{2}\right)
$$

where: $t_{\alpha}\left(f_{2}\right)$ - the value of the Student's criterion.

At the significant level $\alpha=0.025$ and the degree of freedom $\mathrm{f}_{2}=\mathrm{N} \times(\mathrm{k}-1)=8 \times(3-1)=16$ from Table 3.2 [24] obtained $\mathbf{t}_{\mathbf{0 . 0 2 5}}(\mathbf{1 6}) \mathbf{=} \mathbf{2 . 7 7 6 4}$. (6):

The values of the Student's criterion $t_{b j}$ for the coefficients $b_{j}$ are calculated by the formula

$$
t_{b j}=\frac{\left|b_{j}\right|}{S_{b j}}
$$

Estimation of dispersion of coefficients of regression equations $S_{b j}$ are provided by the formula (7):

$$
S_{b j}=\sqrt{\frac{S_{l l}{ }^{2}}{\sum_{i=1}^{N} x^{2}{ }_{j i}}},
$$

where: $S^{2}{ }_{11}-$ estimation of dispersion of observation-error variance, which is determined by the formula (8):

$$
S_{l l}^{2}=\frac{\sum_{i=1}^{m}\left(Y_{o j}-\widehat{Y}_{o}\right)^{2}}{m-1},
$$

where: $\mathrm{m}$ - the number of repeated experiments at the center, $\mathrm{m}=\mathrm{N}_{\mathrm{o}}=5$;

$\mathrm{Y}_{\mathrm{oj}}$ - the obtained value of the $i$-th experiment at the center; 
$\hat{Y}_{0}$ - the average value of $m$ of the experiments at the center of the experimental model, determined by the formula (9):

$$
\widehat{\mathrm{Y}}_{0}=\frac{1}{m} \sum_{n=1}^{m} Y_{o i}=\frac{1}{5} \sum_{i=1}^{5} Y_{o i}=75.37
$$

$\Sigma \mathrm{x}_{\mathrm{ji}}{ }_{\mathrm{ji}}$ - the total number of square columns $\mathrm{x}_{\mathrm{j}}$ of the empirical matrix with two-level layout the optimum level;

$\Sigma \mathrm{x}_{\mathrm{j}}{ }_{\mathrm{j}}=\mathrm{N}$, where: $\mathrm{N}-$ the number of all possible tests, $\mathrm{N}=13$.

Values of the Student's criterion of coefficients of the second-order regression equations (2), (3) and (4) are shown in Table 11.

Table 11. Values of the Student's criterion of coefficients of the second-order regression equations

\begin{tabular}{|c|c|c|c|c|c|c|}
\hline \hline \multirow{2}{*}{$\mathbf{j}$} & $\mathbf{0}$ & $\mathbf{1}$ & $\mathbf{2}$ & $\mathbf{3}$ & $\mathbf{4}$ & $\mathbf{5}$ \\
\cline { 2 - 7 } & $\mathbf{b}_{\mathbf{0}}$ & $\mathbf{b}_{1}$ & $\mathbf{b}_{2}$ & $\mathbf{b}_{12}$ & $\mathbf{b}_{11}$ & $\mathbf{b}_{22}$ \\
\hline $\mathrm{b}_{\mathrm{j} 0}$ & 18.2 & -0.7109 & -1.17 & 0.15 & -0.2188 & -0.3438 \\
\hline$\left|\mathrm{b}_{\mathrm{j} 0}\right|$ & 18.2 & 0.7109 & 1.17 & 0.15 & 0.2188 & 0.3438 \\
\hline $\mathrm{S}_{\mathrm{b} j 0}$ & 0.055 & 0.043 & 0.043 & 0.061 & 0.046 & 0.046 \\
\hline $\mathrm{t}_{\mathrm{b} j 0}$ & $\mathbf{3 3 2 . 2 8 5}$ & $\mathbf{1 6 . 4 1 8}$ & $\mathbf{2 7 . 0 2 0}$ & 2.449 & $\mathbf{4 . 7 0 8}$ & $\mathbf{7 . 3 9 7}$ \\
\hline \hline $\mathrm{b}_{\mathrm{j} 30}$ & 14.34 & -0.717 & -1.376 & 0.3 & 0.1988 & 0.2738 \\
\hline$\left|\mathrm{b}_{\mathrm{j} 30}\right|$ & 14.34 & 0.717 & 1.376 & 0.3 & 0.1988 & 0.2738 \\
\hline $\mathrm{S}_{\mathrm{b} j 30}$ & 0.108 & 0.085 & 0.085 & 0.120 & 0.091 & 0.091 \\
\hline $\mathrm{t}_{\mathrm{b} j 30}$ & $\mathbf{1 3 3 . 1 4 4}$ & $\mathbf{8 . 4 2 1}$ & $\mathbf{1 6 . 1 6 0}$ & 2.491 & 2.175 & $\mathbf{2 . 9 9 6}$ \\
\hline \hline $\mathrm{b}_{\mathrm{j} 60}$ & 10.52 & -1.018 & -1.595 & 0.425 & 0.0838 & 0.2338 \\
\hline$\left|\mathrm{b}_{\mathrm{j} 60}\right|$ & 10.52 & 1.018 & 1.595 & 0.425 & 0.0838 & 0.2338 \\
\hline $\mathrm{S}_{\mathrm{b} j 60}$ & 0.086 & 0.068 & 0.068 & 0.096 & 0.073 & 0.073 \\
\hline $\mathrm{t}_{\mathrm{b} j 60}$ & $\mathbf{1 2 2 . 2 9 3}$ & $\mathbf{1 4 . 9 6 9}$ & $\mathbf{2 3 . 4 5 3}$ & $\mathbf{4 . 4 1 9}$ & 1.147 & $\mathbf{3 . 2 0 3}$ \\
\hline \hline
\end{tabular}

After this checking, the insignificant coefficients are discarded and the following equations are obtained as a result of the experimental model.

The regression equation for the slump cone of the concrete mixture was measured immediately after the completion of the raw materials mixing (10):

$$
\mathrm{y}_{0}=18.2-0.7109 \mathrm{x}_{1}-1.17 \mathrm{x}_{2}-0.2188 \mathrm{x}_{1}^{2}-0.3438 \mathrm{x}_{2}^{2}(\mathrm{~cm})
$$

The regression equation for the slump cone of the concrete mixture was measured after 30 minutes of mixing completion (11):

$$
\mathrm{y}_{30}=14.34-0.717 \mathrm{x}_{1}-1.376 \mathrm{x}_{2}+0.2738 \mathrm{x}_{2}^{2}(\mathrm{~cm}) .
$$

The regression equation for the slump cone of the concrete mixture was measured after 60 minutes of mixing completion (12):

$$
\mathrm{y}_{60}=10.52-1.018 \mathrm{x}_{1}-1.595 \mathrm{x}_{2}+0.425 \mathrm{x}_{1} \mathrm{x}_{2}+0.2338 \mathrm{x}_{2}{ }^{2}(\mathrm{~cm}) .
$$

\section{Checking the adequacy of the experimental model}

The adequacy of the second-order regression equations was checked by means of the Fisher criterion. The calculated value of which is the following ratio (13):

$$
F_{i}=\frac{S_{d}^{2}}{S_{l l}^{2}},
$$

where: $\mathrm{S}^{2}{ }_{11}$ - variance estimates the reproducibility of the experiment, which is determined by formula (14): 


$$
S_{l l}^{2}=\frac{\sum_{j=1}^{m}\left(Y_{o j}-\widehat{Y}_{o}\right)^{2}}{m-1},
$$

where: $\mathrm{m}$ - the number of repeated experiments at the center, $\mathrm{m}=5$;

$\mathrm{Y}_{\mathrm{oj}}$ - the obtained value of the $\mathrm{i}$-th experiment at the center of the experimental model;

$\widehat{Y}_{0}$ - the average value of $\mathrm{m}$ of the experiments at the center of the model;

$\mathrm{S}_{\mathrm{d}}^{2}$ - estimation of the dispersion of inadequacy, determined by the formula (15):

$$
S_{d}^{2}=\frac{\sum_{j=1}^{N}\left(Y_{j}-\hat{Y}_{j}\right)^{2}}{N-B},
$$

where: $\mathrm{B}$ - the number of coefficients of the second-order regression equation, which are significant, $\mathrm{B}=5$;

$Y_{j}$ - the observed value of the $\mathrm{i}$-th experiment;

$\hat{Y}_{j}$ - the obtained value of the experimental function in accordance with the i-th experiment;

$F_{\alpha},\left(f_{1}, f_{2}\right)$ - the value Fisher criterion, which is obtained from table 3.5 [24], with a significant level of $\alpha=0,05$;

where: $f_{1}$ - the number of degrees of freedom for residual variance, $f_{1}=N-B=13-5=8$; $\mathrm{f}_{2}=\mathrm{m}-1=5-1=4$.

$f_{2}$ - the number of degrees of freedom of an estimate of variance of observations,

Consequently: $\mathrm{F}_{0,05}(8,4)=6.0410$.

The regression equation (10): $\mathrm{S}_{\mathrm{d}}^{2}=0.066$ and $\mathrm{S}_{11}^{2}=0.015$ was obtained:

$$
F_{0}=\frac{S_{d}^{2}}{S_{l l}^{2}}=\frac{0.066}{0.015}=4.40 . \text { As } \mathrm{F}_{0}=4.40<\mathrm{F}_{0.05}(8,4)=6.0410, \text { the experimental model }
$$

described by regression equation (10) is adequate.

The regression equation (11): $\mathrm{S}_{\mathrm{d}}^{2}=0.133$ and $\mathrm{S}_{11}^{2}=0.058$ was obtained:

$$
F_{30}=\frac{S_{d}^{2}}{S_{l l}^{2}}=\frac{0.133}{0.058}=2.293 . \text { As } \mathrm{F}_{30}=2.293<\mathrm{F}_{0.05}(8,4)=6.0410 \text {, the experimental }
$$

model described by regression equation (11) is adequate.

The regression equation (12): $\mathrm{S}_{\mathrm{d}}^{2}=0,144$ and $\mathrm{S}_{11}^{2}=0,037$ was obtained:

$$
F_{60}=\frac{S_{d}^{2}}{S_{l l}^{2}}=\frac{0.144}{0.037}=3.892 \text {. As } \mathrm{F}_{60}=3.892<\mathrm{F}_{0.05}(8,4)=6.0410 \text {, the experimental }
$$

model described by regression equation (12) is adequate.

It can be seen in Table 8-10 and in Fig. 2-4, the results of workability determination of concrete mixtures, which are obtained in laboratory conditions, shows the usage of complex organic mineral modifiers. These mineral modifiers, contain RHA, FA TPP "Vung Ang" and superplasticizer ACE 388 in an amount of 1\% of the mass of Portland cement, are relatively effective for workability of concrete mixture. However, they also lead to a decrease in their mobility. It can be explained by the fact that the water requirement of RHA (100.7\%) and FA $(104.1 \%)$ are greater than that of Portland cement (28.58\%). In this case, the superplasticizer ACE 388 reduces the water-cement ratio, thereby increasing the density in the structure of concrete mixture. The average value of slump cone of concrete mixtures measured after 60 
minutes of mixing completion are decreased from 18.2 to $10.52 \mathrm{~cm}$. These values are still within acceptable range for pumping to make possible delivery of concrete mixture.

\section{Conclusions}

Based on the obtained results of the workability of concrete mixes, the following conclusions can be drawn:

1. Using the Central composite rotatable design with the help of Matlab program were obtained second-order regression equations (10), (11) and (12), as well as images of the surface response and corresponding contour plot (shown in Fig. 2 -4). Regression equations adequately describe the dependence of slump cone concrete mixtures on variables $\mathrm{x}_{1}$ amount of RHA and $x_{2}$ - amount of FA, which were added to the concrete mixtures. These values of slump cone of concrete mixture are measured at various time intervals after mixing.

2. On the range of studied concentrations, the content of RHA and FA has a significant influence on the concrete mixture mobility. It can be explained by the fact that the particles of RHA and FA played an important role as peculiar "sliding bearings" between the grains of cement, leading to the dispersion of cement content in the concrete mixture. Therefore, it is possible to regulate the concrete mixture mobility when transporting fresh concrete by pumping during the high-rise construction in the hot and humid climate of Vietnam. In this case, the addition of FA TPP "Vung Ang" in concrete mixtures has a stronger effect to the slump cone as compared with the RHA.

\section{References}

1. Y.M. Bazhenov, Technology of concrete (Publishing. ASV, Moscow, 2011)

2. A.O. Joaquim Barros, Liberato Ferrara, Enzo Martinelli, Recent Advances on Green Concret e for Structural Purposes (Springer International Publishing AG, 2017)

3. S.Yu. Butrim, N.V. Gilyazidinova, Concrete of high-rise constructions. VIII All-Russian scientific-practical conference of young scientists with international participation "Russia is young" (Gorbachev, Kemerovo, 19-22 April, 2016)

4. Ph. D. Huu, Nguyen Ngoc Long, High-strength and high performance concrete (Construction Publishing, Hanoi, 2008)

5. M.V. Komarinsky, N.A. Chervova, Transport of concrete mixture in the construction of unique buildings and structures, Construction of unique buildings and structures, 1(28), 25-30 (2015)

6. S. Jacobsen, et. al Pumping of Concrete and Mortar - State of the Art (COIN Project Report 5, 2008)

7. S. Jacobsen, J.H. Mork, Pumping of Concrete and Mortar (Norwegian Concrete Day, SINTEF, 2007)

8. H Kosmatka Steven and L. Wilson Michelle, Design and Control of Concrete Mixtures (Portland Cement Association, Skokie, Illinois, USA, 2011)

9. S.A. Ambartsumian, A. Martirosyan, A.V. Galumyan, Standards performing concrete work using the bucket and the concrete pump in the high-speed monolithic housing construction, The industrial and civil engineering, 2, 29-30 (2010)

10. M. Haist, H.S. Müller, Optimization of the Pumpability of Self-Compacting Light Weight Concrete (Proc. SCC, ACBM, NWU, Evanston, 2005)

11. N. N. Quy, Studying the Effect of Additives Finely Powdered Limestone and Fly ash Thermal Power to the Properties of the Concrete Mix Pump, Construction Magazine, 
Hanoi, 3, 41 - 44 (2007)

12. L.M. Kolchedantsev, I.G. Osipenkova, Features of organizational and technological solutions in the construction of high-rise buildings, Scientific and technical and industrial, 11, 17-19 (2013)

13. A.M. Neville, Properties of concrete (Publishing. Literature on construction, Moscow, 2003)

14. A.G. Chiknovorjan, Technological design of prefabricated concrete and reinforced concrete production (EBS ASV, Samara State University of Architecture and Civil Engineering, 2010)

15. N. V. Toan, Study on the Effect of Husk Ash and Superplasticizer on the Properties of Lakes, Mortar and Concrete, Journal of Science and Technology, 3+4, 11-51 (2013)

16. Bui Danh Dai, Effects of Active Rice Husk Ash on the Properties of Concrete Mixtures and Mortar, International Scientific Conference "Some New Achievements in Modern Building Materials Research" (Architecture and Civil Engineering, Hanoi, 2008)

17. T. V. Lam, B.I. Bulgakov, O.V. Oleksandrova, O.A. Larsen, The possibility of using ash residues for the production of construction materials in Vietnam, Bulletin of BSTU. V.G. Shukhova, 6, 6- 12 (2017)

18. ACI 211.4R-93, Guide for Selecting Proportions for High-Strength Concrete with Portland Cement and Fly Ash (USA, 2010)

19. V.M. Malhotra, P.K. Mehta, High-Performance, Fligh-Volume Fly Ash Concrete (Ottawa, Canada, 2005)

20. Tang Van Lam, B.I. Bulgakov, O.V. Oleksandrova, Mathematical modeling of the influence of raw components on the strength of high-quality fine-grained concrete under compression, Scientific and Engineering Journal for Construction and Architecture, 9 (108), 999-1009 (2017)

21. N. M. Tuyen, Planning of the Experiment (Publisher of Science and Technology, Hanoi, 2007)

22. L.G. Astakhova, Lectures on the discipline "Mathematical Theory of Experiment Planning" (Vladikavkaz, 2013)

23. T.P. Abomelik, Methodology of experiment planning (Collection of laboratory works for students of specialty 210201.65, Ulyanovsk, 2006)

24. L.N. Bolshev, N.V. Smirnov, Tables of mathematical statistics (Publishing "The science", Moscow, 2010) 